Ta'dib: Journal of Islamic Education

Volume 21, Number 2, December 2016

\title{
The Implementation of Development of School Culture-Based Religious Education
}

\author{
Kurnali Sobandi \\ Universitas Islam At-Thahiriyah Jakarta, Indonesia \\ E-mail:qurnali.sobandi@gmail.com
}

\begin{tabular}{l|l|l}
\hline Received: $29^{\text {th }}$ September 2016 & Revised: $15^{\text {th }}$ October 2016 & Accepted: $21^{\text {th }}$ November 2016
\end{tabular}

\begin{abstract}
In general, religion and religious education serve to create the Indonesian human faith and the obedience to God Almighty, also to create noble, and capable people in maintaining the harmony of inter-religious relations. In addition it serves to cultivate the participants' ability to understand, appreciate and practice the values of religion are offset mastery in science, technology and art. The development of school culture based religious education in public schools is an alternative solution on the problems which are actually classic, but until now they have not been resolved properly, which in turn would be a matter of continuity up from one period to the next, namely the problem of narrow time allocation, three hours for elementary, 2 hours face to face for SMP and SMA / SMK (per-hour 40 minutes instead of 60 minutes) and the problems therein multicultural religious plurality. Implementation of the development of school-culture based religious education in public schools covers the principles of development, through a learning process, learning outcomes assessment, and indicators of school and classroom assessment.
\end{abstract}

Keywords: the Implementation, School Culture Based, Religious Education

\begin{abstract}
Abstrak
Secara umum, agama dan pendidikan agama mencetak manusia Indonesia menjadi beriman, patuh pada Tuhan, juga berakhlak mulia, sehingga mampu mempertahankan hubungan antar umat beragama yang harmonis. Selain itu, pendidikan agama juga berfungsi untuk menumbuhkan kemampuan peserta didik untuk memaahami, menghargai dan mempraktikkan nilai-nilai agama dalam ilmu pengetahuan, teknologi serta seni. Pengembangan pendidikan agama berbasis school culture di sekolah umum adalah solusi alternatif atas problematika yang sebenarnya bersifat klasik, namun hingga kini belum juga terselesaikan dengan baik, sehingga pada gilirannya akan menjadi persoalan yang berkesinambungan hingga dari satu periode ke periode berikutnya yaitu problematika alokasi waktu yang sempit yakni tiga jam untuk SD, 2 jam tatap muka untuk SMP dan SMA/SMK (per-jam bukan 60 menit tetapi 40 menit) dan problematika multikultural didalamnya pluralitas agama. Implementasi pengembangan pendidikan agama berbasis school culture di sekolah umum memuat prinsip pengembangan, melalui proses pembelajaran, penilaian hasil belajar, dan indikator penilaian sekolah dan kelas.
\end{abstract}

Kata Kunci: Implementasi, Budaya Sekolah Berbasis, Pendidikan Agama

\section{Introduction}

The phenomenon of deviations of students religiousity like students brawl events in Indonesia, are at alarming stage, and has cost the lives of the students who are supposed to be the nation's assets next. Among them are persecution, killing their opponents with feelings of guilt and sin. While the incidence of sex outside of marriage also has been a trend among students driven by the increasingly widespread dissemination of VCD tapes, porn sites, and the use of drugs and alcohol. These cases are allegedly a failure indicator of education, especially religious education. This is echoed by Sa'id Agil Husin Al Munawar (2003: 41-42), because religious education is at the castle of the forefront in preparing qualified human resources. It is is not only the intellectual intelligence but also moral 
intelligence and religious education should make significant contribution in creating an increasingly cultured society.

The emergence of the weakness is due to the contradiction between the facts and the expectations or the gap between the reality and ideal ones, the gap between theory and empirical ones. Muhaimin (2006: 17) maps out the weaknesses of religious education in the four main issues, namely: (1) the problems of religious education foundation (foundational problems), (2) the structural problems of religious education (structural problems), (3) operational problem issues of religious education (operational problems), (4) historical issues of religious education (historical problems). Operational areas problems create fundamental problems which cause the issues of religion embraced by the people of Indonesia and the narrow time allocation problems (Nasution, 1995: 1). Selections of the problems are based on the assumption that the issue actually is classic, but until now has not been resolved properly, which in turn would be a matter of continuity up from one period to the next (Muhaimin, 2006: 124). Development of culture SchoolBased Religious Education In Schools is an alternative solution. This becomes a challenge for the schools to implement it.

\section{Religious Education}

Law of the Republic of Indonesia number 20 of 2003 on National Education System (Education Law) formulate the functions and objectives of national education which should be used in developing educational efforts in Indonesia. Article 3 of the Education Law states that "national Education serves to develop and form the character and civilization of the nation's dignity in the context of the intellectual life of the nation, which is aimed at developing students' potentials in order to become men of faith and who have fear of God Almighty, to become noble, healthy, knowledgeable, capable, creative, independent, and to become of democratic and responsible citizens". National education goals are the formulations of Indonesian human beings that should be developed by each educational unit. Therefore, the formulation of national education goals form the basis for the development of the quality of religious education.

There are at least six components of the function and purpose of education which are inferred by Sardiyo, first, the formation of character and civilization of the nation's dignity, secondly, the intellectual life of the nation, the third, men of faith who are obedient to God Almighty, fourth, become noble, healthy bookish, capable, reactive, independent people, fifth, become democratic citizens, and the sixth, become responsible citizens (Sardio, 2009: 210-211).

Furthermore, schools as educational institutions and media as well as human resource development are considered as the most strategic parties to conduct trainingcoaching, both internally, or externally, which led to the independence and progress (Rahim, 2001: 11).

In general, religion and religious education serve to form the Indonesians' human faith and obedience to God Almighty, to have noble character, and to be capable of maintaining the harmony of inter-religious relations. In addition to cultivate the ability of 
The Implementation of Development

of School Culture-Based Religious Education

Kurnali Sobandi

students to understand, appreciate and practice the values of religion that are offset mastery in science, technology and art Fauzan, 2007: 559).

The purpose of religious education in more detail, according to Agus Maimun et al (2003: 3-4), is, first, to instill the values in order to counter the influence of negative or tend to be negative values as a result of globalization. Second, to fight against the tendency of materialism, consumerism and hedonism. Third, to cultivate an understanding and appreciation of the value of justice. Fourth, to instill a strong work ethic as a steppingstone to the world of work and social reality.

Furthermore, Tafsir (2005) in Muhaimin (2006: 123) reinforces the educational purposes of religion (Islam), namely diversity of learners so that not only knowing or doing (practice) but preferably being (religion). To realize these goals Sa'id Agil Husin Al Munawar offers ways to overcome educational purposes including the establishment of implementing moral education at home, school and the community, to integrate between education and teaching. Moral education must be supported by cooperation groups and parents, schools and communities. Schools should seek to create a religious environment and must use all opportunities and a variety of means including modern technology (AlMunawar, 2003: 41-42).

We realize that Indonesia is not a religion based country, but a country with religious famous people, and the people are very strong in animating citizenship life in the country. One aspect of this country's attention is the problem of religious education both in religious and secular educational institutions, both under the responsibility of the government and private sectors. Religious education in religious schools (madrassas) does not face many problems because the time portion is large enough. This is in contrast to the religious education in the public schools. Religious education, both at primary, secondary and especially in college is considered less successful in forminf attitudes and behavioral diversity of learners and in building the nation's morals and ethics. This is because the indicators of the inherent weaknesses in the implementation of religious education in schools which can be identified include: (1) Religious Education does not maximally change religious knowledge, cognitive meaning and values into affective ones that can be internalized by learners, whereas the core of education is on this aspect, (2) Religious Education is less sensitive to social change, so that learners under-appreciate the religious values as the daily values occurred in the community in the socio-cultural context.

In accordance with the Act of 1945 section 29 subsection (1) and (2), and Pancasila as the basic philosophy of the Republic of Indonesia, the religious education is a major public educationand as the foundation of education. Norms of decency education or social and civic education, mostly, if one cannot say everything, is sourced from religion (Purwanto, 1998: 157).

Urgency of religious education for every citizen of Indonesia on the grounds that the process of integration of education formal religion in the national education system in the history of the development of the legal basis (Daulay, 2007: 101-114) has been started since the promulgation of Basic Law of Education No. 4 of 1950 and Education Act No. 
121954 Chapter XII Article 20 concerning the teaching of religion in public schools, which reads:

1. In public schools catechism classes; parents establish whether their children would follow the lesson.

2. How to organize the teaching of religion in public schools is set in the regulations of the Ministry of Education and Culture and the Minister of Religious Affairs (Daulay, 2007: 85-90).

The intimacy of religious education in the national education system increases when the issuance of the Joint Decree (SKB) of three Ministers in 1975, Chapter I Article I, which states that: "The definition of madrasah is an educational institution makes Islamic religious subjects as the basis at least $30 \%$, in addition to general subjects." Religious education is increasingly gaining a strong position following the adoption of national education goals in Law No. 21989 in Chapter II, Section 4 of the National Education System, "National Education aims at making life of the nation smart and developing a complete Indonesian man, the man of faith and devoted to God Almighty and has noble character, knowledge and skills, physical and spiritual health, steady and independent personality, and social and national responsibility (Chapter II, Article 4 UUSPN)."

The cronological historical development of the legal basis for religious education to be one of the lessons in public schools and religion in Indonesia (Tafsir, 2007: 85-90) as follows;

1 June 1, 1945, in the presence of BPUPKI (Committee for Preparatory Work for Indonesian Independence), Sukarno, who later became the President said that how important to be obedient to God for Indonesians.

2 Therefore, on August 18, 1945, Believing in One God was set as the first principle of Pancasila

3 Also in the 1945 Constitution, article 29, paragraph 1 and 2

4 The attitude of the Dutch East Indies faced religious education in public schools in Article 179 (2) I.S. (Indische Staatsregeling) containing that religious instruction should only be applied outside of school hours.

5 On December 27, 1945, BP-KNIP (Working Body of Central Indonesian National Committee) recommended the Ministry of Education, Teaching and Culture (PPK) seek renewal of education and teaching in Indonesia, namely that religious instruction takes the place regularly organized by the ministry of the KDP. Pesantren and Madrasah essence is one of the tools and educational resources that is rooted in the community that should receive attention and government support.

6 The implementation suggestions of BP-KNIP (only implemented on 2 October 1946June 27, 1947, KDP, minister Mr. Kelvin formed a Committee for Teaching Investigators led by K.H. Dewantara who set religious education teaching materials. The work of the committee included:

a. Religious instruction given to all schools within school hours and in the $S R$ started from the Fourth class

b. Religious teachers were provided by the Ministry of Religion and paid by the government. 
The Implementation of Development

of School Culture-Based Religious Education

Kurnali Sobandi

c. Quality Pesantren and madrasah were repaired

7. Determination of the Government no 1, dated January 3, 1946, established the Ministry of Religion

8. Regulation of the Joint Ministerial KDP and the Minister of Religious Affairs in 1947 on the establishment of religious instruction in primary school since fourth grade and was valid from January 1, 1947

9. This was followed by the release of the Basic Education Act No. 4 of 1950 and Education Act No. 12 of 1954 Section XII of Article 20 concerning the teaching of religion in public schools

10. The completion of the Joint Regulation of the Minister of the KDP and the Minister of Religious Affairs in 1951, was the establishment of religious instruction from the first grade

11. The next step was perfecting TAP MPRS No. II of 1960 Chapter II Article 2 paragraph (3) which states that religious subjects in schools applies ranging from elementary school to the state university.

12. TAP MPR No. IV of 1973, namely on the field of religion and belief guidelines that incorporate religious instruction in the school curriculum.

13. The development of increasingly powerful religious education notched after the enactment of national education goals in Law No. 21989 in Chapter II, Section 4 of the National Education System is creating intellectual Indonesians and develop the whole man, the man of faith and devoted to God Almighty and (Article 4). And in Article 39 paragraph, (2) it is stated that the content of the curriculum of every kind, lines and levels of education must include:
a. Pancasila Education
b. Religious Education, and
c. Civic education.

\section{School Culture}

Kent. D. Peterson, terrece. E. Deal (1999), describes that the school culture is a set of values that underlie behavior, traditions, everyday habits, and symbols that practiced by the principal, teachers, administrators, students, and the community around the school. School culture is a whole psychological experience of the learners whether they are social, emotional, and intellectual absorbed by them while in school.

School Culture has very broad scope. It generally includes rituals, hope, relationships, demographics, curricular activities, extra-curricular activities, the process of decision-making, policy and social interaction among components in the school. School culture is the atmosphere of the school where students interact with peers, teachers with teachers, counselors with one another, administration officials with one another, and among members of the school community groups. Internal group and intergroup interactions are bound by various rules, norms, morals and ethics joint force in a school. Leadership, exemplary, friendliness, tolerance, hard work, discipline, social awareness, environmental awareness, sense of nationality, and responsibility are values that are developed in the school culture (Ramly, 2010: 19-20).

All of them formed a school culture that will permeate the psychological 
appreciation of the school community including students who would eventually form the pattern of values, attitudes, habits and behaviors. Muhaimin (2006: 136) classifies the value of the 6 points of view, namely: corner mental abilities and mental development, in terms of cultural process, based on sources. from the standpoint of its scope, substantial angle, and the views of the nature of value .

As confirmation, Rusman (2009: 20) states that the success of a curriculum will be optimal if supported by extracurricular activities which are managed in a comprehensive and integrated intra-curricular activities.

Husni Rahim at.al. (2001: 45) confirms that the position of the religious extracurricular activitiesare undertaken to cover, and provide other nuances in the process of Islamic religious education in the level of intracurricular. Rather than directed to mastering practical and religious skills, students are accustomed to, and create a conducive climate to implement its variety in school environment. Skills in extracurricular religious practice should be enshrined in a curriculum or syllabus including the following procession of dead bodies, Hajj and Umrah, Islamic marriage, leading prayers, praying, the Friday preacher, ratiban, maulidan, azan and iqamah, reading narrator, and prayers of the Prophet, and the prayer after praying.

School culture is integrated into the academic activities and student activities through intra-curricular and extracurricular activities. The activities are not only focused on intracurricular, but also extracurricular activities which can develop creativity, talents and interests of students. School culture must be able to include academic, non-academic, spiritual, arts, sports, and community.

\section{Development of Religious Education}

According Syahidin (2001: 12), the development of religious education is one of the efforts in creating an environment that is better than the previous one. The development of religious education is an effort to optimize functions and roles of all the potentials in the implementation of the teaching and learning process of Religious Education subjects, in order to achieve a better state than the previous situation.

Recognized by Muhaimin (2009: 15-17) that the discourse on the development of religious education in Indonesia has been presented by experts and observers of religious educators which idealistically, romantically, and even less realistically so that stakeholders experience obstacles and difficulties in realizing it.

The development of religious education is the answer to the shortcomings of religious education that takes place in schools during this time. Among the weaknesses of religious education is that it just pays attention to cognitive aspects alone, and ignores the affective and psychomotoric development (Buchori, 1995) not integrate and synchronize with non-religious subjects (Soejatmoko, 1976).

Understanding of the material that is theology leads to a fatalistic ideology, character-oriented manners rather than as a whole religious human person. Worship is 
The Implementation of Development

of School Culture-Based Religious Education

Kurnali Sobandi

understood as a religion, not a routine activity of personality formation (Rasdianah, 1995). Evaluation of the cognitive learning is more dominant than the evaluation of effective and psychomotor learning outcomes (Sudijono, 2000: 198)

Approaches to religious education are still normative. Offering minimum standards of competence, lacking of exploring various efforts such as ensuring the methodology to avoid monotony, limitation of infrastructure (Thowaf, 1996), using behavioristic approach, and not using the constructivist approach.

Religious curriculum is too dense material, and the material is more advanced aspects of thought rather than religious consciousness intact (Mudzhar, 2004).

Not to selectively existing paradigm of religious education that is; still leads to dycotomic paradigm, Paradigm has not yet led to the Mechanism, and not to organism or systemic paradigms.

\section{Schools}

Hadari Nawawi (2005: 25-28) noted the organizational structure of school education paths based on the provisions of Law No. 2 of 1989 on National Education System through the establishment of Government Regulation (PP) as follows:

1. No. 27 of 1990 on preschool education

Forms of education and training unit are as follows: Kindergarten is for children aged 4-6 years, Play Group and Child Care are for children aged at least 3 years, and other similar forms take 1 to 2 years.

2. No. 28 of 1990 on Basic Education

Unit forms of basic education is the six-year primary program, $S D L B$, and $M I$. Basic education unit forms which hold the three-year education program are $S M P L B$, and MTs.

3. Number 29 of 1990 on Secondary Education

Types of secondary education are grouped into two major groups, namely: General Secondary Education in the form of $S M U, M A$, and education in the form of vocational school namely SMK (both SMEA, STM, SMKK, STMA, SAA, SMF, SPG, and $P G A)$.

According to Ivan Illich (1982: 42), the school is a process related to the age limit (age-specific) as well as teachers who are demanding full attendance following the compulsory curriculum. Educational institutions have always regarded as one of the places from which to religious education beside the family (Maimun, 2003: 2).

More specifically Fuad Hasan (2004: 52-66) explained that schooling is a form of education efforts. It is habituation and imitation of a very big influence in education efforts. Education is not just a transfer of knowledge or skills but also includes the transfer of cultural values and social or transmission of culture and social values norms. To more closely see, the school function towards eaching values whether planned or not, interesting explanations by Thomas ( 1997) in Muhaimin (2006: that the education activities in schools, either through learning in the classroom or outside the classroom, are never value- 
free.

In general, religion and religious education serve to create the Indonesian human faith and the obedience to God Almighty, also to create noble, and capable people in maintaining the harmony of inter-religious relations. In addition it serves to cultivate the participants' ability to understand, appreciate and practice the values of religion are offset mastery in science, technology and art (Fauzan, 2007: 559).

According Ngalim Purwanto (1998: 127), the school environment is classified into second environment, after the first is family environment and the third is the community. The obligation of the school, beside teaches (in the sense of simply filling the brains of children with a variety of knowledge), also tries to establish children's good personal human being character. It is useless if the children are very clever and able to pass all of them, but the behavior or character or personality is not good.

School institutions are always seen as one of the places from which to explore religion beside the family. Religious education should be taught in schools, among others are put forward by Al-Mawdudi taken from the teachings of Islam as follows: the appreciation of the meaning of faith and piety, the attitude of helping each other in doing good deeds, have good attitude, respect themselves and others, be responsible for their own actions, have positive attitude to teachers and friends, keep their own belongings and others', time discipline in doing the task, be honest, fair, and wise to themselves and others (Al-Maududi, 1983).

\section{Implementation of School-Based Religious Education Development Culture in Schools}

Mukti Ali said that the activities of religious education and learning, not just to transfer knowledge, but also to perform transactional and transinternalisation. The result is that students are good in cognitive achievement but their commitment of universal value is relatively low. That is why, It is necessary for the development of religious education to the creation of students' noble character (Maimun, 2003: 31).

Religious education is education which is full of attitude formation. According to the Vienna Sanjaya (2007: 271-272), attitude is not to be taught as well as mathematics, physics, social sciences and other sciences, but to be formed. Affective learning strategies are different from cognitive learning strategies and skills. Because affective associated with the value is difficult to measure. Because of growing concerns one's consciousness within certain limits, the affection may arise in the event of behavior, but his assessment to the conclusion accounted requires precision and observations continuously, and it is not easy to do, let alone assess changes in attitudes as a result of the learning process done by the teachers in schools.

The implementation of the development of culture school-based religious education covers the principles of development, through a learning process, learning outcomes assessment, and indicators of school and classroom assessment. 
The Implementation of Development

of School Culture-Based Religious Education

Kurnali Sobandi

\section{Principles of Culture School-Based Religious Education Development}

In principle, School-Based Religious Education Development is not included as a subject because religious education does not merely provide knowledge about the religion, but precisely it is more important in that it gets children to be obedient and submissive worshiper and doer. It also gets students to behave in life according to the norms set out in their respective religions (Purwanto, 1998: 158) with the following principles:

a. Continuously (Ramly, 2010: 19-20)

b. Integrated into subjects (Purwanto, 1998: 158), self-development (Rusman, 2009: 20), the school culture (Ramly, 2010: 19-20).

c. Fun (Maimun, 2003: 31)

Therefore, teachers and schools need to integrate the values developed in religious education into the Education Unit Level Curriculum (SBC), Syllabus and Learning Program Plan (RPP) that already exist.

\section{Assessment of Learning Outcomes}

Muhaimin distinguishes religious education evaluation model into three models according to what will be evaluated. All three models of evaluation are: (1) Group referenced Evaluation Model (evaluation reference norm), (2) Criterian referenced Evaluation Model (evaluation benchmark reference), and (3) Reference of Ethics Model. The development of school culture-based religious education turned out to be judged not just rote short letters, memorizing pillars of prayer and so on, but whether or not students pray regularly. No wonder the need to understand the reference of ethics model arises. This is because something that will be evaluated is the personality. Reference of ethics model is based on the assumption that: the origin of human nature is good, education seeks to develop fitrah (actualization), and the unity of the faith, science, and charity. The implications of assessment of ethical reference model against learning objectives are: to make men "better", in moral, be faithful, and devoted to God. The implications of assessment benchmark of the model towards the learning process is a system to teach value-based instruction, and also the criteria of true/good is absolute (Muhaimin, 2010: 2122).

The assessment of the development of school culture-based religious education is the assessment of learners' affective domain and not their knowledge. Therefore Anas Sudijono (2000: 210-215) emphasized his judgment not on the demands of right and wrong answers, but the specific answers of students, which are about the interests, attitudes, and internalization. Measurements in the framework of affective learning outcomes assessment are often conducted in schools, among others use the test attitude, observation, interviews, and questionnaires.

The evaluation of attainment of development of school culture-based religious education is based on some indicators. For example, an indicator for the value of honesty is formulated as "saying with his real real feelings on what is seen, observed, studied, or perceived", the teacher observes (through various means) whether a learner is honest. Maybe the student expresses his feelings verbally but he can do it in written or even in 
body language. Feelings that otherwise might have gradation of feeling unlike the general his classmates' feelings, even on the contrary to his classmates' common feeling.

Assessment is done continuously, every time the teacher is in the classroom or at school. Model ofanecdotal record (the record of the teacher when views their behavior with respect to the developed value) can always be used by teachers. In addition, teachers can also give a task that contains an issue or event that provides an opportunity for learners to demonstrate its value. For example, the learner is requested to express his attitude towards the efforts to help idlers, to provide assistance to the miser, or other things that are not controversial to the things that can invite conflict in himself.

From observation, anecdotal notes, tasks, reports, and so on, the teacher can give a conclusion or judgment about the achievement of an indicator or even a value. The conclusions or considerations can be expressed in a qualitative statement as follows.

a. BT: Not Seen (if the students do not show early signs of behavior expressed in the indicator).

b. MT: Starting to be Seen (if the students have already started to show early signs of behavior that is expressed in the indicator but not consistently).

c. MB: Starting to Develop (if the students have already shown signs of behavior expressed in the indicator and start to develop the signs consistently).

d. MK: entrenched (if the students continuously exhibit the behavior expressed in the indicator consistently).

There are two types of indicators developed in this guide. Firstly, the indicators for the school and classroom. Indicators of school and classroom are markers used by principals, teachers, and school personnels in planning, implementing, and evaluating schools as the implementing agency of culture religious education development of schoolbased culture. This indicators with regard also to the school daily activities and programmed school activities (routine).

Second, the indicators for the subjects. These indicators describe learners' affective behavior with respect to certain subjects. Indicators are formulated in the form of the behavior of learners in classrooms and schools that can be observed through teachers' observation when the learners perform actions in schools, debriefing with the students, the answers given by learners, the tasks and questions of teachers, as well as the writings of learners in the report and homework. Behavior developed in education indicators culture and national character are progressive. That is, the behavior is growing increasingly complex between one grade level to another grade level (kelas1-3; grades 4-6; 7-9 grade; grade 10-12), and even in the same class level. Teachers have the freedom to determine how long a behavior must be developed before it is upgraded to a more complex behavior. For example, "split the meal to a friend" as an indicator of the level of social awareness in grades 1 - 3. Teachers can develop into "shared food", "shared pencils", "shared books", and so on. 
The Implementation of Development

of School Culture-Based Religious Education

Kurnali Sobandi

\section{Conclusion}

School culture is the atmosphere of the school where students interact with peers, teachers with teachers, counselors one another, with other administration officials, and among members of the school community groups. Internal group and intergroup interactions are bound by various rules, norms, morals and ethics in schools. Leadership, exemplary, friendliness, tolerance, hard work, discipline, social awareness, environmental awareness, sense of nationality, and responsibility are values that are developed in the culture of the school.

The development of school culture based religious education in public schools is an alternative solution on the problems which are actually classic, but until now they have not been resolved properly, which in turn would be a matter of continuity up from one period to the next, namely the problem of narrow time allocation, three hours for elementary, 2 hours face to face for SMP and SMA / SMK (per-hour 40 minutes instead of 60 minutes) and the problems therein multicultural religious plurality.

Implementation of the development of school-culture based religious education in public schools covers the principles of development, through a learning process, learning outcomes assessment, and indicators of school and classroom assessment. 


\section{References}

Al-Munawar, Sa'id Agil Husein. (2003). Aktualisasi Nilai-nilai Qur'an Dalam Sistem Pendidikan Islam. (Jakarta: Ciputat Press.

Buchori, Mochtar. (1992). "Posisi dan Fungsi Pendidikan Agama Islam dalam Kurikulum Perguruan Tinggi Umum.” Makalah, pada Seminar Nasional di IKIP Malang, 24 Februari.

Daulay, Haidar Putra. (2007). Sejarah Pertumbuhan dan Pembaruan Pendidikan Islam di Indonesia. Jakarta: Prenada Media Group.

Fauzan. (2007). "Dilema Baru Pendidikan Islam Pasca Otonomi Daerah", dalam Komaruddin Hidayat,at.al., Mimbar Jurnal Agama dan Budaya Volume 24,No.4, ( Jakarta : UIN Syarif Hidayatullah,.

Nasution, Harun. (1995). Islam Rasional Gagasan dan Pemikiran. Bandung: Mizan.

Maimun, Agus, Abdul Mukti Basri, dan Hasanudin. (2003). Profil Pendidikan Agama Islam (PAI) Sekolah Umum Tingkat Dasar. (Jakarta: Departemen Agama RI Direktorat Jenderal Kelembagaan Agama Islam Direktorat Madrasah Dan Pendidikan Umum Proyek Pemberdayaan Kelembagaan Dan Ketatalaksanaan Pada Madrasah Dan PAI Pada Sekolah Umum Tingkat Dasar.

Muhaimin. (2009). Pengembangan Kurikulum Pendidikan Agama Islam di Sekolah, Madrasah, dan Perguruan Tinggi. Jakarta: PT. RajaGrafindo Persada.

Muhaimin. (2006). Nuansa Baru Pendidikan Islam Mengurai Benang Kusut Dunia Pendidikan. Jakarta: PT.Raja Grafindo Persada.

Peterson. Kent. D., Terrece. E. Deal,. (2009). Shaping School Culture,Pitfalls,Paradoxs \& Promises. Sun Fransisco,USA: Jossey Bass A. Willay Imprint.www.josseybass.

Purwanto, Ngalim. (1998). Ilmu Pendidikan Teoritis Dan Praktis. Bandung: PT. Remaja Rosdakarya.

Rahim, Husni et.al., (2001). Kendali Mutu Pendidikan Agama Islam. (Jakarta: Departemen Agama RI Direktorat Jenderal Pembinaan Kelembagaan Agama Islam.

Ramly, Mansyur. (2010). Pengembangan Pendidikan Buadaya Dan Karakter Bangsa Pedoman Sekolah. Jakarta: Kementerian Pendidikan Nasional Badan Penelitian dan Pengembangan Pusat Kurikulum. Edit. M. Amin Abdullah, dkk. Yogyakarta: DIP PTA IAIN Sunan Kalijaga.

Rasdianah. (1995). Butir-butir Pengarahan Dirjen Binbaga Islam pada Pelatihan Peningkatan Wawasan Ilmu Pengetahuan dan Kependidikan Bagi Dosen PAI di Perguruan Tinggi Umum. Bandung, 11 Desember.

Rusman. (2009). Manajemen Kurikulum. Jakarta: Rajawali Pers.

Sardiyo. (2009). "Multikulturalisme: Paradigma Pendidikan Berbasis Kebangsaan (Suatu Tinjauan Kritis Terhadap Fenomena Masyarakat Melalui Pendekatan Sosiokultural" dalam, Edit. Fuad A.Hamied dan Syihabuddin, Memelihara kerukunan melalui pendidikan multikultural. Jakarta: Kedeputian Bidang Koordinasi Pendidikan, Agama dan Aparatur Negara.

Soejatmoko. (1976). "Pengaruh Pendidikan Agama Terhadap Kehidupan social." Makalah, disajikan pada Seminar Pendidikan Agama dan Sistem Pendidikan Bangsa, Jakarta 28-31 Januari 1976.

Sudijono, Anas. (2000). Strategi Evaluasi Hasil Belajar Pendidikan Agama Islam Ranah Afektif (Kajian MikroKurikulum Sekolah umum tahun 1994) dalam Antologi Studi Islam Teori \& Metodologi . Syahidin. (2001). Disertasi Pengembangan 
The Implementation of Development

of School Culture-Based Religious Education

Kurnali Sobandi

Pendidikan Agama IslamDi Perguruan Tinggi Umum Studi Kasus Di IKIP Bandung Tahun 1966 - 1999. Jakarta: SPs UIN Syarif Hidayatullah.

Tafsir, Ahmad. (2008). Metodologi Pengajaran agama Islam. Bandung: Remaja Rosdakarya.

Thowaf. (1996). Siti Malikhah,Pembinaan Kampus Sebagai Lembaga Pendidikan Ilmiah Edukatif yang Religius". Makalah Disajikan dalam Konvensi Nasional Pendidikan III. Ujung Pandang, 4-7 Maret 1996. 
The Implementation of Development of School Culture-Based Religious Education Kurnali Sobandi

Ta'dib: Journal of Islamic Education - Volume 21, Number 2, December 2016 P-ISSN: 1410 - 6973; E-ISSN: 2443 - 2512

Available online at http:/ / jurnal.radenfatah.ac.id/ index.php/ tadib 